\title{
Development of Blended Learning-Based Parenting Program for Working Parents with Infants and its Effect on Parents' Verbal Behaviors, Responsiveness and Co-Parenting
}

\author{
Hye Young Shin ${ }^{1}$, Myoung Soon Kim² \\ Ph. D., Department of Child and Family Studies, Yonsei University, Seoul, Korea ${ }^{1}$ \\ Professor, Department of Child and Family Studies, Yonsei University, Seoul, Korea ${ }^{2}$ \\ 만 1세 영아의 맞벌이 부모 동반참여 블렌디드러닝 부모교육 프로그램의 \\ 개발 및 효과: 부모의 언어적 행동, 반응성 및 공동양육을 중심으로 \\ 신혜영 ${ }^{1}$, 김명순 ${ }^{2}$ \\ 연세대학교 아동가족학과 박사 ${ }^{1}$, 연세대학교 아동가족학과 교수 ${ }^{2}$
}

Objectives: This study aimed to develop a blended learning-based parenting program and examine its effects on the quality of verbal behavior, responsiveness, and co-parenting of working parents with one-year-old infants.

Methods: Since both parents were working, the 'Blended Learning' method, which integrates online and offline sessions, was used. To evaluate the effectiveness of the developed program, 43 pairs of working parents, each having a one-year-old child were recruited (24 pairs in the experimental groups and 19 pairs in the control group). Parental verbal behaviors, responsiveness, and coparenting were assessed before and after the eight-week program. The data were analyzed with ANCOVA using the pretest score as a covariate.

Results: The parenting program was developed through the following five steps derived from the ADDIE model development process: analyzing, designing, developing, implementing, evaluating. The program lasts for eight weeks and consists of four offline and eight online training sessions. After participating in the program, the parents in the experimental group showed improvement in their verbal behaviors and responsiveness during play interactions. There was no significant difference between the experimental group and the control group on the co-parenting assessment scores.

Conclusion: The blended learning-based parenting program proved to be effective in improving the quality of working parents' verbal behaviors and responsiveness.

Keywords: infant, working parents, parenting program, blended learning, verbal behaviors, responsiveness, co-parenting

\section{Introduction}

영아기는 발달의 기초가 형성되는, 생애의 어느 시기보다 중요

Corresponding Author: Myoung Soon Kim, Professor, Department of Child and Family Studies, Yonsei University, 50, Yonsei-ro, Seodaemun-gu, Seoul, Korea

E-mail: kimms@yonsei.ac.kr
성이 강조되는 시기이며(Bornstein, 2002), 특히 첫 돌이 지난 만 1 세 영아는 첫 단어를 말하고 첫 걸음을 떼는 등 성장 발달에 있어 급격한 진전이 이루어지는 결정적 시기를 맞게 된다(M. S.

(C)The Korean Association of Child Studies

This is an Open Access article distributed under the terms of the Creative Commons Attribution Non-Commercial License (http:// creativecommons.org/licenses/by-nc/4.0) which permits unrestricted noncommercial use, distribution, and reproduction in any medium, provided the original work is properly cited. 
Kim, 2019). 이 시기 영아는 부모와의 상호작용에서 주도적인 행동을 더 시도하므로, 부모가 영아를 이끄는 것보다는 영아의 주의와 의도를 따르면서 영아를 지지하며 반응적으로 상호작 용하는 것이 중요하다(Masur, Flynn, \& Lloyd, 2013). 부모는 이 과정에서 영아의 월령과 발달 단계에 따라 자신의 언어수준과 유형을 변형하여 상호작용을 하는데(Flynn \& Masur, 2007), 이 때 사용하는 부모의 언어적 행동은 영아지지 또는 부모주도 언 어적 행동으로 구분할 수 있다. 영아지지 언어적 행동은 부모 가 영아의 의도를 파악하고 영아가 주의를 기울이고 있는 것에 부모가 공동으로 주의집중하며 반응하는 언어 자극을(Flynn $\&$ Masur, 2007), 부모주도 언어적 행동은 영아의 현재 주의 또 는 행동으로부터 새로운 주의로 전환하도록 부모가 주도하는 언어 자극을 의미하며, 여러 선행연구 결과는 영아지지 언어적 행동이 부모주도 언어적 행동보다 영아의 언어발달에 긍정적 인 영향을 미치는 것으로 보고하고 있다(Choi \& Kim, 2019; M. S. Kim \& Sung, 2002; Y. S. Lee \& Kim, 2013; Masur et al., 2013). 영아의 주의와 의도를 따르며 상호작용을 하기 위해서는 부모 의 반응성이 필요하다. 반응적인 부모는 영아의 선택과 결정 을 존중하는 영아 중심적인 태도를 보이며, 영아의 정서를 수 용하고 지지해줌으로써 긍정적인 관계를 형성하게 된다(Gates, 2007; H. J. Kim \& Kim, 2019; Ko \& Lee, 2010). 반면, 반응적이 지 못한 부모의 경우 영아가 보내는 메시지를 정확히 읽어내 지 못하거나 무시하고 영아의 흥미와 주의에 상관없이 부모 주도적인 행동을 강요하거나 영아의 시도를 방해한다(Frodi, Bridges, \& Grolnick, 1985; Stern, 2002).

또한, 만 1 세 영아 후반 걸음마기가 시작되면서부터 부모의 공동양육에 대한 요구와 중요성이 더욱 부각된다. 아버지와 어 머니는 양육에서 각자 역할과 영향력이 다를 뿐 아니라 자녀 와의 상호작용과 반응성 측면에서도 질적으로 다른 고유성을 가지고 있음을 연구 결과들이 제시하고 있다(M. S. Kim, Cho, Park, \& Shin, 2013; Ko \& Lee, 2010; Pancsofar \& Vernon-Feagans, 2006). 부부가 자녀를 기르는 책임을 함께하는 공동양육자로 서(Schoppe-Sullivan, Mangelsdorf, Frosch, \& McHale, 2004; van Egeren \& Hawkins, 2004), 협력적인 양육이 이루어질 때, 부모 자신에게 직접적인 영향은 물론 상대 배우자의 정서적 안녕과 바람직한 양육태도로 이어져 자녀의 긍정적 발달에 이르게 된 다(LeRoy, Mahoney, Pargament, \& DeMaris, 2013). 따라서 자녀 의 긍정적인 발달을 위해 부모의 언어적 행동, 반응성, 부부간 협력적인 공동양육의 질을 증진시킬 수 있도록 자녀 출생 후 초기부터 전문적 지원이 필요하다. 특히 맞벌이 부모는 양육에 관한 실질적인 정보 습득에 대한 요구도와 부모교육의 참여의
향은 매우 높지만 질 높은 교육 접근성 및 기회 측면에서는 부 족함을 느끼고 있다(E. Kim, Chang, Kim, \& Walker, 2011). 맞 벌이 부모에게 있어 부모역할을 수행하는 것이 스트레스보다 는 즐거운 상황으로 인식되고 부모나 자녀의 건강한 성장과 적 응력을 이끌어 내기 위해서, 개방적이고 지지적인 교육에 지속 적으로 참여하는 경험(M. S. Kim, 2016)은 매우 중요하며 이는 맞벌이 부모 모두에게 필요하다(Garbarino, Vorrasi, \& Kostelny, 2002). 부모교육이란 분명한 교육대상과 이들의 특성에 따라 증진시키거나 변화시키고자 하는 구체적인 목표, 분명한 내 용을 가지고 조직적인 노력을 하는 것으로 정의된다(Smith, Perou, \& Lesesne, 2002). 맞벌이 부모 대상의 프로그램에서는 기존의 부모교육에서 강조되었던 연령별 자녀의 발달과업에 맞춘 교육내용과 더불어 직장과 가정에서 부부가 담당하고 있 는 다양한 역할에 대해 서로 지지할 수 있는 협력적인 공동양 육의 관점에 초점을 맞추는 것이 필요하다. 또한, 맞벌이 부모 처럼 특정 시간과 장소에서 이루어지는 부모교육에 현실적인 참여가 어렵다는 점(M. S. Kim, 2016; Y. Lee, Kim, \& Lim, 2016) 과 주입식의 일회성 대집단 집합교육이 아닌 부모의 능동적 참 여를 독려하는 다양한 형태로 이루어져야 한다는 점(Bae, Cho, Bong, \& Kim, 2011; Myers-Walls \& Dworkin, 2015; S.-H. Park \& Choi, 2010)을 고려해볼 때 맞벌이 부모들의 상황과 요구에 적 합한 맞춤형 교육이 절실히 요구된다.

이때, 프로그램에 참여한 대상에게 교육 내용을 잘 전달하 기 위한 운영 방식은 중요한 전략 중의 하나이다. 이를 위해 교 수자와 학습자간 뿐 아니라 학습자들간의 상호작용성을 최대 화하는 오프라인 학습과 시공간의 제약을 극복하면서 학습 의 효과를 높일 수 있는 온라인 학습의 두 장점을 적절히 혼합 한 블렌디드러닝 수업 방식(Thorne, 2003)을 고려해볼 수 있 다. 블렌디드러닝은 이론과 실습이 통합되는 교육맥락에서 유 용하기 때문에 양육지식과 기술 습득, 태도 변화를 모두 중요 시하는 부모교육에 적합하다고 할 수 있다(Cha, Moon, Yoon, $\& \mathrm{Kim}, 2005)$. 블렌디드러닝에서 학습은 일회성이 아닌 지속 적인 과정이라는 기본전제를 두며(Singh \& Reed, 2001), 교수 자 중심의 틀에 박힌 교육에서 벗어나 학습자 중심의 자기주 도 학습을 지원할 수 있는 융통성을 제공한다(Singh \& Reed, 2001), 이러한 블렌디드러닝의 특징은 학습자의 자기조절 및 개별화학습능력 증진을 도와 프로그램의 효과성을 높일 수 있 다(Acree et al., 2017; Rivera, 2017). 특히 시간적 제약이 있는 맞 벌이 부모를 대상으로 동반참여 부모교육 프로그램을 개발할 때 공동양육관계에 있는 아버지와 어머니가 가지는 고유성과 차이점을 서로 인정하면서 개별 학습을 촉진할 수 있을 뿐만 
아니라 일·가정 병행으로 인한 교육 참여의 부담을 감소시킬 수 있는 효율적 운영 방식이 될 것이다.

영아를 양육하는 맞벌이 부모가 협력적인 공동양육관계를 유지하며 자녀에게 민감하고 반응적으로 상호작용하는 것은 부모-자녀관계의 기초를 형성하고 이후의 관계발전에 매우 중 요하다. 국내 영아 프로그램의 경우 사회관계능력 향상에 편중 되어있는 실정이며(Chung, Yee, \& Moon, 2012), 최근에 정부의 유관 부처 및 관련 기관들이 다양한 부모교육 프로그램을 개발 하여 보급하고 있지만 전업주부인 어머니 대상의 교육이 대다 수이고 자녀 연령이 폭넓게 설정되어 있으며, 아버지와 맞벌이 부모를 특정 대상으로 하거나 부와 모가 함께 참여하는 등의 세분화된 부모교육은 미흡하다(G. Kim, 2017; W. Park, Lee, \& $\mathrm{Ye}, 2018)$. 따라서 생애 초기이며 결정적 시기인 만 1 세 영아 자 녀를 둔 맞벌이 아버지와 어머니 모두를 대상으로 공동양육관 계 측면에서 영아 발달에 적합한 부모의 언어적 행동과 반응적 상호작용(H. J. Kim \& Kim, 2019; LeBarton, Goldin-Meadow, \& Raudenbush, 2015; Masur et al., 2013; S. Park \& Kim, 2020)을 내 용으로 하는 부모 동반참여 형식의 교육 프로그램이 개발될 필 요가 있다. 교육 방법적인 측면에서도 시간적, 물리적 제약으 로 인해 부모교육에 대한 진입 장벽을 낮추고자 온.오프라인을 통합한 블렌디드러닝 방식(Mantyla, 2001; Singh \& Reed, 2001) 을 적용하는 것은 의미가 있다 하겠다.

이에, 본 연구에서는 만 1 세 영아를 둔 맞벌이 아버지와 어머 니를 대상으로 부모의 언어적 행동, 반응성 및 공동양육 관계의 질 증진을 위한 부모 동반참여 블렌디드러닝 부모교육 프로그 램을 개발하고, 개발된 프로그램의 효과를 검증하는 것을 목적 으로 하였다. 특히 만 1 세 영아를 둔 맞벌이 부모들의 부모교육 에 대한 요구를 반영하여 부부가 같은 프로그램에 참여하여 학 습내용을 공유하며 부부공동양육을 적용, 실천할 수 있다는 점 에서 본 프로그램의 장점이 크다고 할 수 있다. 본 연구의 결과 는 만 1 세 영아 부모의 언어적 행동과 반응성의 질을 높이는 구 체적인 방안을 제공하고, 부부가 협력적인 공동양육자로서 자 녀의 생애 초기의 긍정적 발달을 이끄는 성공적인 부모 역할을 수행할 수 있는 기반을 마련해줄 것이라고 기대한다.

\section{연구문제 1}

만 1세 영아의 맞벌이 부모 동반참여 블렌디드러닝 부모교육 프로그램의 목표, 내용, 운영방식, 교수학습방법은 무엇인가?

\section{연구문제 2}

만 1 세 영아의 맞벌이 부모 동반참여 블렌디드러닝 부모교육
프로그램은 아버지와 어머니의 언어적 행동, 반응성 및 공동 양육의 질을 변화시키는가?

2-1. 부모교육 프로그램은 아버지-영아, 어머니-영아 상호작 용에서 아버지와 어머니의 언어적 행동의 질을 변화시 키는가?

2-2. 부모교육 프로그램은 아버지-영아, 어머니-영아 상호 작용에서 아버지와 어머니의 반응성의 질을 변화시키 는가?

2-3. 부모교육 프로그램은 아버지와 어머니가 서로 지각한 공동양육의 질을 변화시키는가?

\section{Methods}

\section{만 1 세 영아의 맞벌이 부모 동반참여 블렌디드 러닝 부모교육 프로그램 개발}

본 연구는 만 1 세 영아를 둔 맞벌이 부모 동반참여 블렌디드러 닝 부모교육 프로그램 개발에 앞서 적합한 개발 절차를 구상 하기 위해 프로그램 개발에 관한 모형 도출 및 관련 문헌, 선행 연구를 고찰하였다. 이러한 이론적 근거를 바탕으로 본 연구 가 만 1 세 영아를 둔 맞벌이 가정 부모를 대상으로 그들의 양 육 행동 변화를 목표로 한 교육 프로그램 개발과 실행이 목적 인 점에 비춰볼 때, 교수체제개발의 기본 모형이라 할 수 있는 $\mathrm{ADDIE}$ 모형에 근거하여 개발하는 것이 적합하다고 판단하였 다. 이에 변화이론에서 강조하는 프로그램 과정의 인과적 메커 니즘을 점검할 수 있는 프로그램 요소들을 본 모형의 교수학습 방법에 접목하여 $\mathrm{ADDIE}$ 모형의 5단계 절차에 맞춰 프로그램 개발을 진행하였다. 본 프로그램 개발 모형 및 각 단계별 내용 은 Figure 1에 제시하였고, 그 내용을 기술하면 다음과 같다.

먼저, 첫 단계 '분석'에서는 문헌고찰 및 관련 이론들을 토 대로 교육 대상 특성 및 프로그램 요구, 내용, 운영방식에 대해 분석하였다. 그 다음 '설계' 단계에서는 본 프로그램의 구체적 인 목표를 설정하고, 목표 달성을 위한 학습내용, 교수모형, 학 습과정 및 교수학습방법과 프로그램의 효과 검증을 위한 평가 방법을 설계하였다. 온라인과 오프라인 교육을 통합한 '격주 제 블렌디드러닝 독립 교수모형'을 적용하였으며, 1 세 영아 자 녀를 둔 맞벌이 부모들이 영아발달에 대한 지식과 자녀와의 


\begin{tabular}{|c|c|c|c|}
\hline Analyzing & \multicolumn{3}{|c|}{$\begin{array}{l}\text { - Analyzing Characteristics \& Needs of Participants } \\
\text { - Analyzing Contents \& Teaching Methods of the Program }\end{array}$} \\
\hline \multicolumn{4}{|l|}{$\downarrow$} \\
\hline Designing & \multicolumn{3}{|c|}{$\begin{array}{l}\text { - Setting Goals } \\
\text { - Selecting Content } \\
\text { - Selecting Teaching Strategies } \\
\text { - Selecting Evaluation Method }\end{array}$} \\
\hline \multicolumn{4}{|l|}{$\downarrow$} \\
\hline Development & \multicolumn{3}{|c|}{ - Developing Program Activity Plans \& Online-Offline Teaching Materials } \\
\hline \multirow{6}{*}{ Implementation } & \multirow{6}{*}{$\begin{array}{l}\text { - Implementation of the } \\
\text { Program } \\
\text { - Maintaining and } \\
\text { Managing the } \\
\text { Program: Task } \\
\text { Performance Check } \\
\text { and Feedback }\end{array}$} & $\begin{array}{l}\text { Session } \\
1 \\
\text { (offline) }\end{array}$ & $\begin{array}{l}\text { - Lecture \& Introduction of the Topic } \\
\text { - Application: Small Group Activities } \\
\text { (demonsration, discussion, role-playing, etc.) } \\
\text { - Guidance for online sessions }\end{array}$ \\
\hline & & & $\downarrow$ \\
\hline & & $\begin{array}{l}\text { Session } \\
2-1 \\
\text { (online) }\end{array}$ & $\begin{array}{l}\text { - Lecture \& In-Depth Learning (1) } \\
\text { - Application: Individual Activities } \\
\text { - Self-Reflection }\end{array}$ \\
\hline & & $\begin{array}{l}\text { Session } \\
2-2 \\
\text { (online) }\end{array}$ & $\begin{array}{l}\text { - Lecture \& In-Depth Learning (2) } \\
\text { - Application: Individual Activities } \\
\text { - Self-Reflection } \\
\text { - Guidance for offline training }\end{array}$ \\
\hline & & & $\downarrow$ \\
\hline & & & (Repeating the same format up to Session 8-2) \\
\hline$\downarrow$ & & & \\
\hline Evaluation & $\begin{array}{l}\text { - Evaluating the Effectiv } \\
\text { - Observing \& analyzing } \\
\text { - Co-parenting question } \\
\text { - Program satisfaction q } \\
\text { - Program implementati }\end{array}$ & $\begin{array}{l}\text { 's play int } \\
\text { alysis } \\
\text { raire analy } \\
\text { ess analys }\end{array}$ & iction (parents' verbal behavior and responsiveness) \\
\hline
\end{tabular}

Figure 1. Development of the blended learning-based parenting education program.

효과적 상호작용 기술을 습득하고 양육에 대한 신념과 태도 의 변화를 통해 언어적 행동과 반응성, 공동양육의 질이 증진 할 수 있는 내용을 포함하였다. 세 번째 '개발' 단계에서는 분 석과 설계 과정을 통해 추출한 결과를 토대로 회기 및 집단형 태, 강사를 선정하고, 주 1 회, 1 시간 오프라인과 주 2회, 20분 내외의 온라인 교육을 격주로 실시하는 총 8주, 12 회기 블렌 디드러닝 부모교육의 내용을 운영방식에 맞게 구성, 조직하
였다. 또한 프로그램을 적용할 때 사용할 교수자료를 제작하 고 온라인 운영 플랫폼을 세팅하였다. 네 번째 '실행' 단계에 서는 개발한 부모교육 프로그램을 1 세 영아의 맞벌이 부모를 대상으로 실시하였다. 마지막 ‘평가' 단계에서는 본 프로그램 의 목표 달성 여부를 확인하기 위해 효과 검증과 프로그램 만 족도를 분석하였다. 
Table 1

Socio-Demographic Characteristics of the Subjects

\begin{tabular}{|c|c|c|c|c|c|c|c|}
\hline \multirow{2}{*}{\multicolumn{2}{|c|}{ Variables }} & \multicolumn{2}{|c|}{ Experimental group } & \multicolumn{2}{|c|}{ Comparative group } & \multicolumn{2}{|c|}{ Total } \\
\hline & & $\begin{array}{l}\text { Fathers } \\
(n=24)\end{array}$ & $\begin{array}{l}\text { Mothers } \\
(n=24)\end{array}$ & $\begin{array}{l}\text { Fathers } \\
(n=19)\end{array}$ & $\begin{array}{l}\text { Mothers } \\
(n=19)\end{array}$ & $\begin{array}{l}\text { Father } \\
(n=43)\end{array}$ & $\begin{array}{l}\text { Mothers } \\
(n=43)\end{array}$ \\
\hline \multirow[t]{4}{*}{ Age } & 26-30 years & $2(8.3)$ & $5(15.8)$ & $1(5.3)$ & $3(15.8)$ & $3(7.0)$ & $8(18.6)$ \\
\hline & $31-35$ years & $9(37.5)$ & $13(52.6)$ & $6(31.6)$ & $10(52.6)$ & $15(34.9)$ & $23(53.5)$ \\
\hline & $36-40$ years & $11(45.8)$ & $5(20.8)$ & $11(57.9)$ & $6(31.6)$ & $22(51.2)$ & $11(25.6)$ \\
\hline & 41-45 years & $2(8.3)$ & $1(4.2)$ & $1(5.3)$ & $0(0.0)$ & $3(7.0)$ & $1(2.3)$ \\
\hline \multirow[t]{5}{*}{ Education level } & High school diploma & $0(\quad 0.0)$ & $0(0.0)$ & $2(10.5)$ & $0(\quad 0.0)$ & $2(4.7)$ & $0(0.0)$ \\
\hline & College & $1(4.2)$ & $0(0.0)$ & $1(5.3)$ & $0(0.0)$ & $2(4.7)$ & $0(0.0)$ \\
\hline & Bachelor's degree & $19(79.2)$ & $21(87.5)$ & $9(47.4)$ & $13(68.4)$ & $28(65.1)$ & $34(79.1)$ \\
\hline & Master's degree or higher & $3(12.5)$ & $3(12.5)$ & $7(36.8)$ & $6(31.6)$ & $10(23.3)$ & $9(20.9)$ \\
\hline & Unknown & $1(4.2)$ & $0(0.0)$ & $0(0.0)$ & $0(0.0)$ & $1(2.3)$ & $0(0.0)$ \\
\hline \multirow{3}{*}{$\begin{array}{l}\text { Employment } \\
\text { type }\end{array}$} & Full-time & $24(100.0)$ & $21(87.5)$ & $17(89.5)$ & $17(89.5)$ & $41(95.3)$ & $38(88.4)$ \\
\hline & Part-time & $0(\quad 0.0)$ & $3(12.5)$ & $1(5.3)$ & $2(10.5)$ & $1(2.3)$ & $5(11.6)$ \\
\hline & Unknown & $0(\quad 0.0)$ & $0(\quad 0.0)$ & $1(5.3)$ & $0(\quad 0.0)$ & $1(2.3)$ & $0(0.0)$ \\
\hline \multirow[t]{6}{*}{ Occupation } & Administrative management & $1(4.2)$ & $1(4.2)$ & $2(10.5)$ & $3(15.8)$ & $3(7.0)$ & $4(9.3)$ \\
\hline & Profession & $6(25.0)$ & $13(54.2)$ & $6(31.6)$ & $7(36.8)$ & $12(27.9)$ & $20(46.5)$ \\
\hline & Office work & $15(62.5)$ & $9(37.5)$ & $6(31.6)$ & $7(36.8)$ & $21(48.8)$ & $16(37.2)$ \\
\hline & Sales/service & $1(4.2)$ & $1(4.2)$ & $1(5.3)$ & $0(\quad 0.0)$ & $2(4.7)$ & $1(2.3)$ \\
\hline & Business & $0(\quad 0.0)$ & $0(0.0)$ & $1(5.3)$ & $1(5.3)$ & $1(2.3)$ & $1(2.3)$ \\
\hline & Others & $1(4.2)$ & $0(0.0)$ & $3(15.8)$ & $1(5.3)$ & $4(9.2)$ & $1(2.3)$ \\
\hline
\end{tabular}

Note. $N=86 . N(\%)$.

\section{만 1 세 영아의 맞벌이 부모 동반참여 블렌디 드러닝 부모교육 프로그램 효과 검증}

\section{연구대상}

프로그램 효과 검증을 위한 본 연구의 대상은 서울과 경기지 역에 거주하고 있는 만 1세 영아(16개월에서 23개월)와 그들 의 아버지, 어머니를 각각의 쌍으로 하여 총 43 쌍, 129 명이었 다. 아버지와 어머니는 모두 주 40 시간 이상 근무하는 맞벌이 로서 육아휴직자도 대상에 포함하였다. 참여자 모집은 눈덩이 표집과 해당지역의 육아 커뮤니티 및 SNS를 통해 이루어졌으 며, 모집 과정에서 총 8 주간의 교육 프로그램 참여와 2 회 영상 촬영에 모두 참여를 원하는 26쌍은 참여집단에, 2 회 영상촬영 에만 참여를 원하는 20 쌍은 비교집단으로 배정하였다. 이 중, 참여집단의 경우 26 쌍이 모두 교육에는 참여하였으나, 집단 간 동질성 검증과정에서 이상치(outlier)에 속하는 2 쌍이 제외 되었으며, 비교집단의 경우 1 쌍의 부모가 8 주 이후에 개인적
사정으로 사후검사에 참여하지 못해 탈락되었다. 최종적으로 참여집단과 비교집단 각각 24 쌍, 19 쌍이 프로그램의 효과 검 증 연구 대상자로 선정되었으며, 사전검사 점수에 대한 집단 간 동질성 검사를 수행한 결과 두 집단 간 유의한 차이가 나타 나지 않아 동질성을 확보하였다.

본 연구 참가자의 일반적 특성을 영아와 부모별, 참여집단 과 비교집단별로 살펴보면 다음과 같다. 참여집단과 비교집 단 영아의 평균 월령은 19.5 개월과 20.5 개월이었으며 월령 범 위는 15 개월 24 개월로 같았다. 참여집단의 남녀 성비는 12 명 $(50.0 \%)$ 으로 같았으며, 비교집단은 남아가 8 명(42.1\%), 여 아가 11 명(57.9\%)으로 여아가 많았다. 형제 순위는 참여집단 의 경우, 첫째가 22 명 $(91.6 \%)$, 둘째가 2 명 $(8.3 \%)$ 이었으며, 비 교집단은 첫째가 12 명 $(63.2 \%)$, 둘째가 6명 $(31.6 \%)$, 셋째가 1 명 $5.3 \%)$ 로 두 집단 모두 첫째가 많았다. 영아의 기관경험은 참여집단과 비교집단 모두 기관을 경험한 영아 비율이 각각 $70.8 \%, 78.9 \%$ 이었으며, 재원 평균기간은 참여집단 영아가 7.0 개월, 비교집단 영아가 8.6개월이었다. 다음으로, 참여집단과 
비교집단 아버지의 평균 연령은 각각 35.96세 $(S D=3.55)$ 와 35.41 세 $(S D=2.93)$ 이었고, 어머니의 평균 연령은 참여집단은 33.58 세 $(S D=3.15)$, 비교집단은 33.15세 $(S D=3.58)$ 이었다. 집 단별 연구 대상 부모의 연령, 교육수준, 고용형태, 직업 등의 일반적 특성은 Table 1에 제시하였다.

\section{연구도구}

블렌디드러닝 부모교육 프로그램 실시 전후 프로그램 효과 검 증을 위해 부모의 언어적 행동 분석 범주, 부모 반응성 척도, 부모공동양육 척도를 사용하였다.

\section{부모의 언어적 행동 분석 범주}

부모의 언어적 행동을 분석하기 위하여 Flynn과 Masur (2007) 의 범주를 예비조사를 통해 만 1 세 영아 부모에 적합하게 수 정·보완하여 사용하였다. 먼저, 부모가 발화시점에서 영아의 주의를 따르는지 여부에 따라 영아지지(attention-follow) 언어 적 행동과 부모주도(attention-lead) 언어적 행동으로 구분하였 다. 다음으로 부모의 화용론적 의도에 따라 영아지지 언어적 행동은 설명, 파악질문, 교수질문, 권유, 피드백의 다섯 가지 하위 범주로, 부모주도 언어적 행동은 행동지시와 주의지시의 두 가지 하위 범주로 구분하였다. 각 하위범주의 조작적 정의 를 자세히 살펴보면 다음과 같다. 영아지지 언어적 행동 중 '설 명'은 영아가 현재 주의를 기울이고 있는 사물, 행동, 상황이나 사건에 대해 명명하거나 묘사하는 것, '파악질문'은 영아가 현 재 주의를 기울이고 있는 사물, 행동에 대해 부모가 영아의 의 도, 관심, 행동을 알기 위해 묻는 것, '교수질문'은 영아가 현재 집중하고 있는 사물 또는 행동에 대해 부모가 영아를 가르치 거나 영아의 수준을 평가하려는 의도를 가지고 질문하는 것을 의미한다(Pine, 1992). 또한, '권유'는 영아가 현재 주의를 집중 하고 있는 사물과 관련하여 진행중인 활동을 지지, 확장하려 는 의도로 영아에게 제안, 명령 또는 격려하여 영아가 행동이 나 언어로 표현하도록 하는 것, “피드백'은 “옳지, 똑똑하네.”와 같이 영아가 현재 주의를 집중하고 있는 사물과 관련한 행동 에 대해 인정, 칭찬, 격려 등으로 반응하는 것을 의미한다. 반 면, 부모주도 언어적 행동 중 ‘행동지시'는 영아가 현재 주의를 기울이고 있는 사물이나 활동을 제한하거나 제지하려는 의도 또는 영아가 현재 주의집중하고 있지 않은 사물이나 활동에 대하여 영아가 행동하고 언어로 표현하도록 하는 것, ‘주의지 시'는 영아가 현재 주의를 집중하고 있는 사물이나 진행중인
활동으로부터 부모가 원하는 곳으로 영아의 주의(관심)을 돌 리도록 하는 것을 의미한다. 위의 범주에 포함되지 않는 부모 의 언어적 행동은 '기타'로 분류하였다. 부모의 언어적 행동은 아버지-영아, 어머니-영아간 10 분의 놀이 상호작용에서 나타 난 아버지와 어머니의 발화를 모두 전사한 후, 녹화영상을 보 면서 발화 단위로 빈도를 산출하여 분석하였다. 부모의 언어 적 행동에 대한 관찰자 간 신뢰도는 적률상관계수 $r=.93$ 으로 나타났다.

\section{부모의 반응성 척도}

부모의 반응성을 살펴보기 위해, Gates (2007)의 부모 반응성 측정도구의 범주를 본 연구 목표에 적합하도록 예비조사를 거쳐 수정, 보완하였으며, 부모-영아 놀이 상호작용에서 언어 적으로 이루어지는 상호 반응성을 함께 살펴보기 위해 Shuler (2012) 연구에서 사용된 공동주의와 상호교환 범주를 추가하 여 사용하였다. 최종적으로 영아 중심성, 민감성, 정서적 수용 성, 참여성, 공동주의, 상호교환의 6 개 하위 범주로 구분하였 다. 점수의 평정은 촬영된 아버지-영아, 어머니-영아의 10 분 동안의 놀이 상호작용 행동을 관찰하여 각 하위범주에 대해 평정 기준에 따라 1 점에서 5 점 사이로 점수를 부여하였다. 부 모 반응성에 대한 관찰자간 신뢰도는 $r=.89$ 로 나타났다.

\section{부모공동양육척도}

만 1 세 영아자녀를 둔 맞벌이 가정의 부부가 지각하는 부모공 동양육 관계의 변화를 조사하기 위해 Margolin, Gordis와 John (2001)이 개발한 공동양육 질문지(Coparenting Questionnaire [CQ])를 사용하였다. 본 척도는 협력적 공동양육 5 문항, 갈등 적 공동양육 5 문항, 삼각화 공동양육 4 문항으로 3 가지 하위 범주 총 14 문항으로 구성되었다. 협력적 공동양육 항목은 부 부가 양육자로서 서로의 역할을 지지하고, 양육가치관을 존 중하며 책임을 함께 나누는 정도, 갈등적 공동양육 항목은 양 육을 하면서 발생하는 부부간 갈등 및 서로 다른 양육 방식이 나 기준의 정도를 측정한다. 마지막으로, 삼각화 공동양육 항 목은 부부간에 자녀를 갈등 상황으로 끌어들여 상대 양육자 를 배제하거나 무시하는 것을 측정하는 내용으로 구성되어 있 다. 문항에 대한 응답은 부 또는 모가 공동양육 파트너인 모 또 는 부를 생각하며 자기 보고식으로 보고하며 부정적으로 서 술된 문항의 경우 역채점하여 합산한다. 각 문항은 Likert식 5 점 척도를 사용하여 결코 그렇지 않다(1점)부터 항상 그렇다(5 
점)까지 체크하도록 되어있다. 본 척도의 내적 합치도 계수를 Cronbach's $\alpha$ 로 산출한 결과, 협력적 공동양육 .78, 갈등적 공 동양육 .81 , 삼각화 공동양육 .69 이다.

\section{연구절차}

본 연구는 본교 생명윤리위원회(IRB)로부터 심의, 승인(IRB No. 7001988-202007-HR-654-03)을 받고 연구 대상자를 모집 하였으며, 이후 다음의 다섯 단계에 걸쳐 프로그램 효과검증 을 진행하였다.

$$
\text { 예비조사 }
$$

본 조사 전에 아버지-영아, 어머니-영아 놀이 상호작용을 촬영 하기 위해 사용하는 놀잇감의 적절성, 소요 시간, 측정 도구 및 방법의 적절성, 분석 기준의 적합성 등을 살펴보기 위해 예비 조사를 실시하였다.

\section{평정자 훈련}

부모의 언어적 행동 분석 범주와 반응성 평정을 위한 관찰자 훈련을 실시하였다. 평정자는 아동가족학을 전공하는 대학원 생 1 명과 본 연구자로 총 2 명이었으며, 평정자간 의견이 일치 하지 않는 부분은 재평정과 논의를 통해 $80 \%$ 이상 일치도가 나올 때까지 의견을 조정하였다.

\section{사전검사}

부모교육 프로그램을 실시하기 전, 2019년 9월 말부터 10월 말 까지 참여집단과 비교집단의 아버지와 어머니 모두에게 사전 검사를 실시하였다. 본 연구자가 직접 가정으로 방문하였으며, 두 집단 모두 연구 참여자의 윤리적인 보호를 위해 심의 승인 받은 연구참여자 설명문을 안내하고 연구 동의서에 부모의 서 명을 받았다. 부모 중 한 명이 영아와 놀이 상호작용 촬영을 시 작하면 또 다른 부모는 다른 공간으로 이동하여 부모공동양육 척도 및 인구학적 배경 질문지를 작성하였다. 예비조사를 토대 로 최종 분석 영상 10 분 이외에 여유시간을 포함해 15 분 정도 촬영을 진행하였다. 첫 번째 놀이 촬영 후, 영아의 주의 전환 및 간식, 배변 등을 위해 30 분 정도 휴식 시간을 가지고 나서 두 번 째 촬영을 진행하였다. 촬영 종료 후 참여집단 부모에게는 이 후 진행될 8 주간의 부모교육 프로그램의 일정 안내를, 비교집
단은 8주 후에 진행될 사후 검사 일정을 안내하였다.

$$
\text { 교육 프로그램 실시 }
$$

사전검사가 완료된 이후, 2019년 10월 중순부터 12월 중순까 지 참여집단의 아버지와 어머니만을 대상으로 본 연구에서 개 발한 ‘만 1 세 영아의 맞벌이 부모 동반참여 블렌디드러닝 부모 교육 프로그램'을 실시하였다. 참여 집단 부모는 8 주 동안 격 주로 이루어지는 온.오프라인 12회기를 학습하면서 매 주 생 활적용 과제를 제시받아 수행하였으며, 이 과정에서 깨달은 점, 어려운 점 등을 스스로 되돌아보고 일기 형식으로 자아성 찰일지를 작성하여 온라인 앱에 업로드하였다. 반면, 비교집 단은 별도의 교육에 참여하지 않았다.

\section{사후검사 및 프로그램 평가}

참여집단과 비교집단의 부모 모두에게 사전검사와 동일한 절 차로 2019년 12월 중순부터 2020년 1월 중순까지 사후검사를 실시하였다. 참여집단의 경우, 8 주 본 프로그램을 모두 마친 후에 진행하였으며, 온.오프라인의 교육 내용과 운영에 대한 만족도 조사와 내용 평가 및 참여 효과를 묻는 평가 설문지도 함께 작성하였다. 반면, 프로그램에 참여하지 않은 비교집단 의 경우, 사전검사 실시 후 8 주 후가 되는 시점에 맞춰서 사후 검사를 실시하였으며, 부모교육의 차원에서 온라인 교육 프로 그램을 안내하고 희망하는 경우 동영상 강의를 수강할 수 있 도록 하였다.

\section{자료분석}

개발한 교육 프로그램의 효과를 검증하기 위해 본 연구에서 수집된 자료를 SPSS WIN 25.0 (IBM Co., Armonk, NY)를 이 용하여 다음과 같은 방법으로 분석하였다. 먼저, 연구 대상자 의 일반적 특성을 살펴보기 위해 빈도와 백분율, 평균과 표준 편차를 산출하였으며, 각 변인의 정규성 검정을 위해 ShapiroWilk test를, 참여집단과 비교집단의 동질성 검정을 위해 일원 변량분석(One-way ANOVA)을 실시하였다. 또한, 만 1세 영아 의 맞벌이 부모의 언어적 행동, 반응성, 공동양육에서의 질의 변화를 분석하기 위하여 참여 및 비교집단의 사전, 사후검사 점수의 평균과 표준편차를 산출하였으며, 프로그램 효과를 검 증하기 위해 각 변인들의 사전점수를 공변인으로 한 공변량 분석(ANCOVA)을 각각 실시하였다. 


\section{Results}

\section{부모교육 프로그램 개발}

\section{교육목표}

본 프로그램은 발달의 기초가 형성되며, 성장 발달에 있어 급격 한 진전이 이루어지는 만 1 세 영아를 둔 맞벌이 부모를 대상으 로 다음과 같은 세 가지 목표를 선정하였다. 선정된 목표와 그 에 따른 하위목표는 다음과 같다. 첫째, 부모의 언어적 행동의 질을 증진하는 것으로, 영아지지 언어적 행동을 늘리고 부모주 도 언어적 행동을 줄이는 것이다. 둘째, 부모의 반응성의 질을 향상하는 것으로, 이를 위한 하위 목표로는 자녀의 주도를 따 라가는 영아 중심성 증진하기, 자녀의 신호나 요구에 대한 민 감성 증진하기, 긍정적인 정서적 수용성 증진하기, 자녀 수준에 맞춘 활동 참여성 증진하기, 부모의 공동주의 증진하기, 부모영아 상호교환 증진하기를 포함하였다. 마지막으로, 부모의 공 동양육의 질을 향상하는 것으로, 부모공동양육의 협력적 관계 를 강화하고 부모공동양육의 부정적 관계를 약화하는 것이다.

\section{교육 내용 및 운영 방식}

이론적 고찰을 통해 최종 도출된 핵심주제는 '놀이를 통한 부 모-자녀 상호작용, 언어적 상호작용, 반응적 상호작용, 부모됨 과 부모공동양육' 이었으며, 각 주제에 맞게 매 회기마다 부모 가 자녀와의 놀이시 영아지지 언어적 행동과 반응성 그리고 협 력적 공동양육 관계 증진을 위한 세부 교육 내용을 구성하였다.

각 회기별 학습과정은 Kolb (1984)가 제시한 4단계 학습과 정을 본 연구 대상자에 맞게 수정하여 오프라인과 온라인 교 육 12회기 모두 '동기 유발', '정보 습득', '기술 훈련', '생활 적 용', '자기 성찰(또는 사전학습확인)'의 5단계 순환적 과정으로 적용하였다. 구체적인 내용 구성의 예는 다음과 같다. 1 회기 오프라인 교육의 경우, 강사소개 및 상호인사(10분), 블렌디드 러닝 기반 부모교육 프로그램 소개(10분)를 포함하여 총 90 분 으로 구성되었다. 5단계 학습과정 중 첫 번째인 동기 유발에 서는 부모들이 원하는 놀잇감을 가지고 개별 또는 소그룹별로 자유 놀이를 하였다(15분). 이러한 활동을 바탕으로 강사의 강 의와 학습자의 질의응답을 통해 1 회기 학습 주제인 놀이의 중 요성과 특징, 놀이환경으로서의 부모역할에 대해 정보 습득 이 이루어지도록 하였다(30분). 3 단계 기술 훈련에서는 <오늘 의 놀이>를 통해 부모-자녀 놀이 상호작용 방법을 안내하고,
강사의 시범을 보면서 부부가 짝이 되어 상호작용을 훈련하였 다(15분). 생활 적용에서는 자녀의 놀이행동 관찰 과제를 제시 하였으며, 부모가 가정에서 과제를 실천하고 자기성찰일지를 작성하며 자기성찰을 하도록 안내하였다. 다음 2-1회기 온라 인 교육을 안내한 후 1차시 오프라인 교육을 마무리하였다(10 분). 세부 교육 내용 구성 후, 교육 목표 달성을 위한 최적의 흐 름을 고려하여 총 8주 12 회기에 맞추어 주제와 세부 교육 내 용을 회기별 순서에 따라 적절한 온.오프라인 운영방식을 조 직, 구성하였다. 최종 개발된 격주제 블렌디드러닝 독립 교수 모형을 적용한 본 프로그램의 각 회기별 주제와 내용은 Table 2 에 제시하였다. 이를 구체적으로 살펴보면, 1 회기(오프라인) 는 부모들이 원하는 놀잇감으로 직접 자유놀이를 해본 후 소 감을 나누고(동기유발), 이를 바탕으로 놀이의 중요성과 특징, 놀이환경으로서의 부모역할에 대해 강의가 이루어졌다(정보 습득). 밀가루 반죽놀이를 통해 감각적인 탐색의 중요성과 놀 이상호작용을 연습하였으며(기술훈련), 자녀의 놀이행동 관 찰 과제를 제시하였다(생활적용). 2-1회기(온라인)는 영아의 놀이 발달 및 특징에 대해 구체적인 동영상사례와 함께 온라 인 주제강의가 이루어지고, 집에서 쉽게 할 수 있는 스펀지 목 욕소품을 이용한 감각놀이방법을 영상으로 소개하였다. 2-2 회기(온라인)는 부와 모 상호작용의 고유성과 주고받는 상호 작용의 중요성에 대해 강의한 후 물이나 티슈로 쉽게 지워지 는 수성크레용을 활용하여 마음껏 끼적여보는 놀이를 하며 주 고받기 상호작용을 연습하도록 하였다. 부모들이 매주 제시된 과제를 실천하고, 놀이사진이나 동영상을 첨부하여 온라인 앱 에 자기성찰일지를 업로드하도록 하였다. 3 회기(오프라인)는 아버지, 어머니별로 배우자 역할의 강, 약점에 대해 소그룹 토 의를 하면서 공동양육의 어려움, 필요성을 공감하였으며, 이 에 대한 강의가 이루어졌다. 개방형 놀잇감인 종이벽돌블록 을 이용하여 다양한 방법으로 반복하고 탐색하며 영아와 상 호작용하는 방법을 실습하였으며, 양육자간 역할분담표를 작 성하고 공동양육을 실천해보는 과제를 제시하였다. 4-1회기 (온라인)는 맞벌이 가정의 하루 동영상을 통해 현재 맞벌이 가 족의 현실적 어려움을 되돌아보며 부모공동양육에 대한 노력 을 강조하였다. 협력적 공동양육을 적용할 수 있는 구체적 예 시들을 제공하였으며, 오늘의 놀이 영상에서는 스카프를 활용 한 까꿍놀이로 반응적 상호작용을 안내하였다. 4-2회기(온라 인)에서는 만 1 세 영아들이 놀이와 일상에서 자주 보이는 비 언어적 신호를 포함한 영아의 의사소통에 대해 구체적인 동영 상 사례와 함께 강의가 이루어졌으며, 오늘의 놀이인 '나처럼 해봐라. 요렇게'를 통해 부모가 영아의 신호나 요구에 대한 민 
Table 2

Contents of Sessions

\begin{tabular}{|c|c|c|c|}
\hline Session & Week & Topic & Contents \\
\hline 1 & $\begin{array}{l}1 \\
\text { (offline) }\end{array}$ & Playing with the infant & $\begin{array}{l}\text { - Orientation } \\
\text { - Understanding of play } \\
\text { - Parents as play environment } \\
\text { - Today's play < How does it feel?: Exploration play> }\end{array}$ \\
\hline 2 & $\begin{array}{l}2-1 \\
\text { (online) }\end{array}$ & Enhancing infant's play & $\begin{array}{l}\text { - Characteristics of infant development } \\
\text { - Age-specific development and types of play } \\
\text { - Today's play <Floating sponges: Exploration play> }\end{array}$ \\
\hline 3 & $\begin{array}{l}2-2 \\
\text { (online) }\end{array}$ & Infant-parent play interaction & $\begin{array}{l}\text { - Importance of play interaction } \\
\text { - Uniqueness of fathers' and mothers' interaction } \\
\text { - Serve \& return interaction and parent's play participation } \\
\text { - Today's play <Let's scribble: Expression play> }\end{array}$ \\
\hline 4 & $\begin{array}{l}3 \\
\text { (offline) }\end{array}$ & Understanding parenting and co-parenting & $\begin{array}{l}\text { - Understanding 'parenting' } \\
\text { - Importance of parenting in infancy } \\
\text { - The concept and necessity of co-parenting } \\
\text { - Today's play < Playing with cardboard blocks: Exploration play> }\end{array}$ \\
\hline 5 & $\begin{array}{l}4-1 \\
\text { (online) }\end{array}$ & Co-parenting for working parents & $\begin{array}{l}\text { - Current situation of working parents } \\
\text { - The concept of gate keeping } \\
\text { - Application of co-parenting for working parents } \\
\text { - Today's play <Scarf peekaboo: Language play> }\end{array}$ \\
\hline 6 & $\begin{array}{l}4-2 \\
\text { (online) }\end{array}$ & Communication in infancy & $\begin{array}{l}\text { - What is communication? } \\
\text { - Development of communication skills in infancy } \\
\text { - Reactive Interaction with infant } \\
\text { - Today's play < Move like me: Physical play> }\end{array}$ \\
\hline 7 & $\begin{array}{l}5 \\
\text { (offline) }\end{array}$ & Verbal interaction with infant & $\begin{array}{l}\text { - Importance of picture book reading } \\
\text { - Environment for picture book reading } \\
\text { - Reading picture books with infant } \\
\text { - Co-parenting through picture book reading } \\
\text { - Today's play <My favorite book: Language play> }\end{array}$ \\
\hline 8 & $\begin{array}{l}\text { 6-1 } \\
\text { (online) }\end{array}$ & Joint attention in picture book reading & $\begin{array}{l}\text { - Various types of picture books } \\
\text { - How to choose picture books for infants } \\
\text { - Today's play <Blanket sledding: Physical play> }\end{array}$ \\
\hline 9 & $\begin{array}{l}6-2 \\
\text { (online) }\end{array}$ & Pretend play & $\begin{array}{l}\text { - What is pretend play and why is it important? } \\
\text { - Development of pretend play in infancy } \\
\text { - Supporting infant's pretend play } \\
\text { - Today's play < There is my baby: Pretend play> }\end{array}$ \\
\hline 10 & $\begin{array}{l}7 \\
\text { (offline) }\end{array}$ & Responsive parenting in everyday life & $\begin{array}{l}\text { - Development of the self and emotion in infancy } \\
\text { - Definition of responsiveness and its influence } \\
\text { - Four stages of discipline and co-parenting in discipline } \\
\text { - Today's play <Put the ball in the hole: Exploration play> }\end{array}$ \\
\hline 11 & $\begin{array}{l}8-1 \\
\text { (online) }\end{array}$ & Outdoor play & $\begin{array}{l}\text { - Definition of outdoor play and its value } \\
\text { - How to support outdoor play: autonomy and initiative in infancy } \\
\text { - Today's play <Let's take a walk!: Outdoor play> }\end{array}$ \\
\hline 12 & $\begin{array}{l}8-2 \\
\text { (online) }\end{array}$ & Program review \& evaluation & $\begin{array}{l}\text { - Reviewing what we have learned } \\
\text { - Today's play <Spin the waterwheel: Water-sand play> } \\
\text { - Program evaluation }\end{array}$ \\
\hline
\end{tabular}


Table 3

Date, Time, and Place for Offline Training and Number of Participants

\begin{tabular}{|c|c|c|c|c|}
\hline \multirow[b]{2}{*}{ Class } & \multirow[b]{2}{*}{ Dates \& Times } & \multirow[b]{2}{*}{ Place } & \multicolumn{2}{|c|}{ Participants $(n)$} \\
\hline & & & Fathers & Mothers \\
\hline A & $\begin{array}{l}\text { 10/19, 11/2,11/16,11/30 } \\
\text { Sat. 10:00-11:00 }\end{array}$ & $\begin{array}{l}\text { Kindergarten } \\
\text { (Bundang-gu, Gyeonggi-do) }\end{array}$ & 5 & 5 \\
\hline $\mathrm{B}$ & $\begin{array}{l}\text { 11/2, 11/16, 11/30, 12/14 } \\
\text { Sat. 13:00-14:00 }\end{array}$ & $\begin{array}{l}\text { Kindergarten } \\
\text { (Bundang-gu, Gyeonggi-do) }\end{array}$ & 7 & 7 \\
\hline $\mathrm{D}$ & $\begin{array}{l}\text { 10/26, 11/9, 11/23, 12/7 } \\
\text { Sat. 14:00-15:00 }\end{array}$ & $\begin{array}{l}\text { ECE institution } \\
\text { (Seodaemun-gu, Seoul) }\end{array}$ & 8 & 8 \\
\hline Total & \multicolumn{2}{|c|}{4 Classes (16 Trainings) } & 24 & 24 \\
\hline
\end{tabular}

감성 늘리기를 실습하였다. 5회기(오프라인)에서는 만 1 세 영 아들에게 적합한 책읽기 방법을 살펴보고 부부가 함께 연습을 해본 후 전체 교육생을 대상으로 스토리텔링을 하였다. 자녀 와 그림책 읽기를 통해 영아지지적 언어 사용을 늘리도록 생 활적용과제를 제시하였다. 6-1회기(온라인)에서는 영아기 그 림책 선정 기준과 다양한 종류의 그림책 실물을 소개하는 온 라인강의와 '선이의 이불' 그림책과 연계한 이불 놀이를 안내 하였다. 특히, 엄마, 아빠만의 고유성을 살려 각자의 방법으로 자녀와 책읽기를 수행해보도록 격려하였다. 6-2회기(온라인) 에서는 만 1 세 후반 영아기에 나타나는 놀이 발달의 주요한 특 징 중 하나인 상징 놀이에 대하여 살펴보고, 아기돌보기 놀이 를 통해 부모가 효과적인 놀이상호작용하는 방법을 배우고 연 습하였다. 7회기(오프라인)에서는 부모양육태도를 스스로 체 크해보고 만 1 세 후반 영아기 발달에 적합한 양육태도, 훈육을 통한 반응적 양육 증진하기에 대해 구체적으로 살펴보았다. 소그룹 활동으로 훈육의 4단계 전략과정을 실습한 후 이를 역 할극을 통해 발표하도록 하였다. 8-1회기(온라인)에서는 급격 한 신체 발달이 이루어지는 만 1 세 후반 영아기에 중요한 활동 중 하나인 바깥놀이의 가치를 다양한 실외활동을 모은 영상을 통해 강조하고, 바깥놀이터에서 영아지지 언어적행동과 반응 적 상호작용 연습을 하도록 시연영상을 제공하였다. 8-2회기 (온라인)는 전체 교육내용을 리뷰하고, 맞벌이 가정의 유아자 녀부터 성인자녀들이 부모에 대한 격려와 감사를 전하는 영상 으로 마무리하였다.

\section{프로그램 실시}

본 프로그램은 총 8 주 12 회기 블렌디드러닝 부모교육 프로그
램으로 개발되었으며, 오프라인 교육은 격주로 주 1 회씩 총 4 회기, 회기 당 60 분 -90 분 이내로, 8-15명 정도의 소 또는 중집 단 형태로 실시되었다. 교육 장소는 부모의 이동접근성을 고 려하여 서울, 경기 3 곳의 거점교육기관을 선정하였으며, 맞벌 이 부모의 회사업무 또는 영아 질병 등으로 인한 수업 결손을 최소화하기 위하여 반별 교육 시작을 다르게하여 토요일 오 전/오후반으로 나눠서 총 4개 반으로 운영하였다. 오프라인 교육 날짜, 시간, 장소 그리고 참여한 부모들의 수는 Table 3에 제시하였다.

온라인 교육은 오프라인 교육과 격주로 한 주에 2 회씩 총 8 회기, 회기당 20 분 내외로 모바일 앱을 통하여 부모들이 원하 는 시간과 장소에서 학습이 이루어졌다. 이를 위해 현재 국내 공교육을 보완하는 커뮤니티이자 학습 플랫폼으로 사용 중인 교육용 애플리케이션인 클래스팅(classting)을 선정하였다. 참 여 집단 부모들은 아버지, 어머니 각자의 계정으로 해당 앱에 회원가입을 해서 온라인 교육에 개별적으로 모두 참여하였으 며 학습 수행 후 댓글을 통해 출석 체크가 이루어졌다. 특히 부 모는 생활 적용 과제 수행 후 자아 성찰일지를 온라인 교육 공 간에 글, 사진, 영상 등과 함께 업로드하여 다른 부모들이나 강 사로부터 수행 피드백을 받을 수 있고, 자녀 문제에 대한 $1: 1$ 강사와의 상담 등이 온라인 교육 공간에서 이루어졌다.

\section{부모교육 프로그램 효과 검증}

$$
\text { 부모의 언어적 행동의 질 변화 }
$$

본 부모교육 프로그램 실시 여부에 따라 차이가 있는지를 살 
Table 4

Results of ANCOVA of Parents' Verbal Behaviors

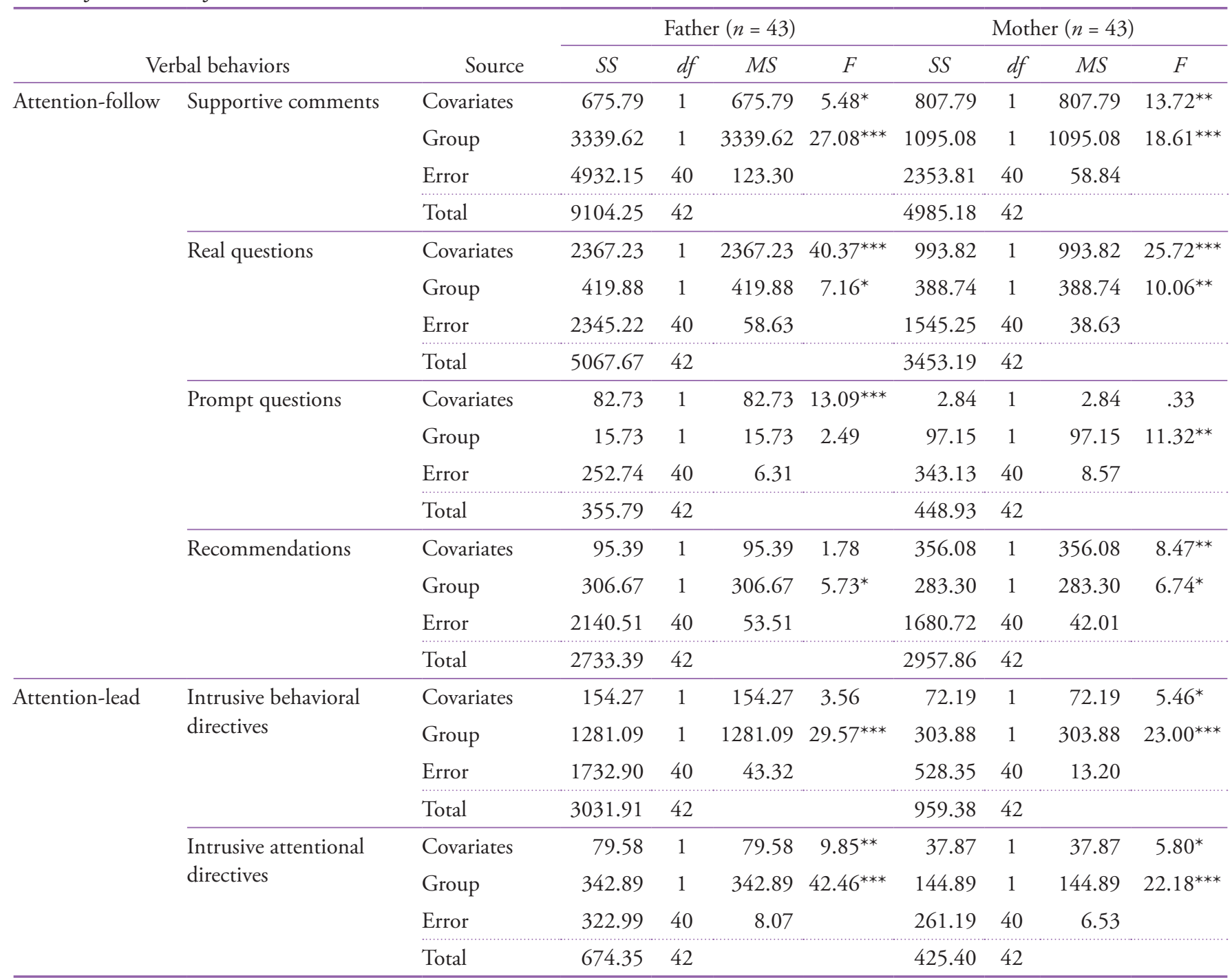

Note. $N=86$. Father $n=43$; Mother $n=43$.

${ }^{*} p<.05 .{ }^{* *} p<.01 .{ }^{* * *} p<.001$.

펴본 결과(Table 4 참조) 참여집단 부모의 언어적 행동의 질에 서 유의미한 차이가 있었다. 영아지지 언어적 행동에서는 아 버지, 어머니 모두 설명, 파악질문, 권유에서, 교수질문은 어머 니에서만 집단 간 유의미한 차이가 나타났다. 즉, 교육에 참여 한 참여집단 아버지와 어머니가 비교집단 부모에 비해 영아를 지지하는 설명과 파악질문을 사용하는 언어적 행동이 증가하 였고, 권유는 감소하였다. 또한, 참여집단 어머니의 경우 영아 에게 가르치려는 의도를 가진 교수질문이 교육 실시 후에 감 소하였다. 한편, 부모주도 언어적 행동에서는 참여집단 아버 지와 어머니 모두 영아가 현재 집중하고 있는 행동과 주의를 방해하는 부모주도 행동지시, 주의지시가 감소하였다.

\section{부모의 반응성의 질 변화}

본 프로그램이 참여집단 부모의 반응성의 질을 변화시켰는지 분석한 결과는 Table 5에 제시하였다.

Table 5와 같이, 참여집단의 아버지와 어머니 모두, 비교집 단 아버지와 어머니에 비해 반응성의 하위 항목인 영아 중심 성, 민감성, 정서적 수용성, 참여성, 공동주의, 상호교환에서 유의미한 차이가 나타났다. 즉, 부모교육에 참여한 참여집단 아버지와 어머니 모두 비교집단 부모에 비해 교육 실시 후에 자녀의 자율성과 주도성을 존중하는 영아 중심적인 태도를 가 지며, 자녀의 신호와 요구에 민감하게 반응을 하고, 공동주의 
Table 5

Results of ANCOVA of Parents' Responsiveness

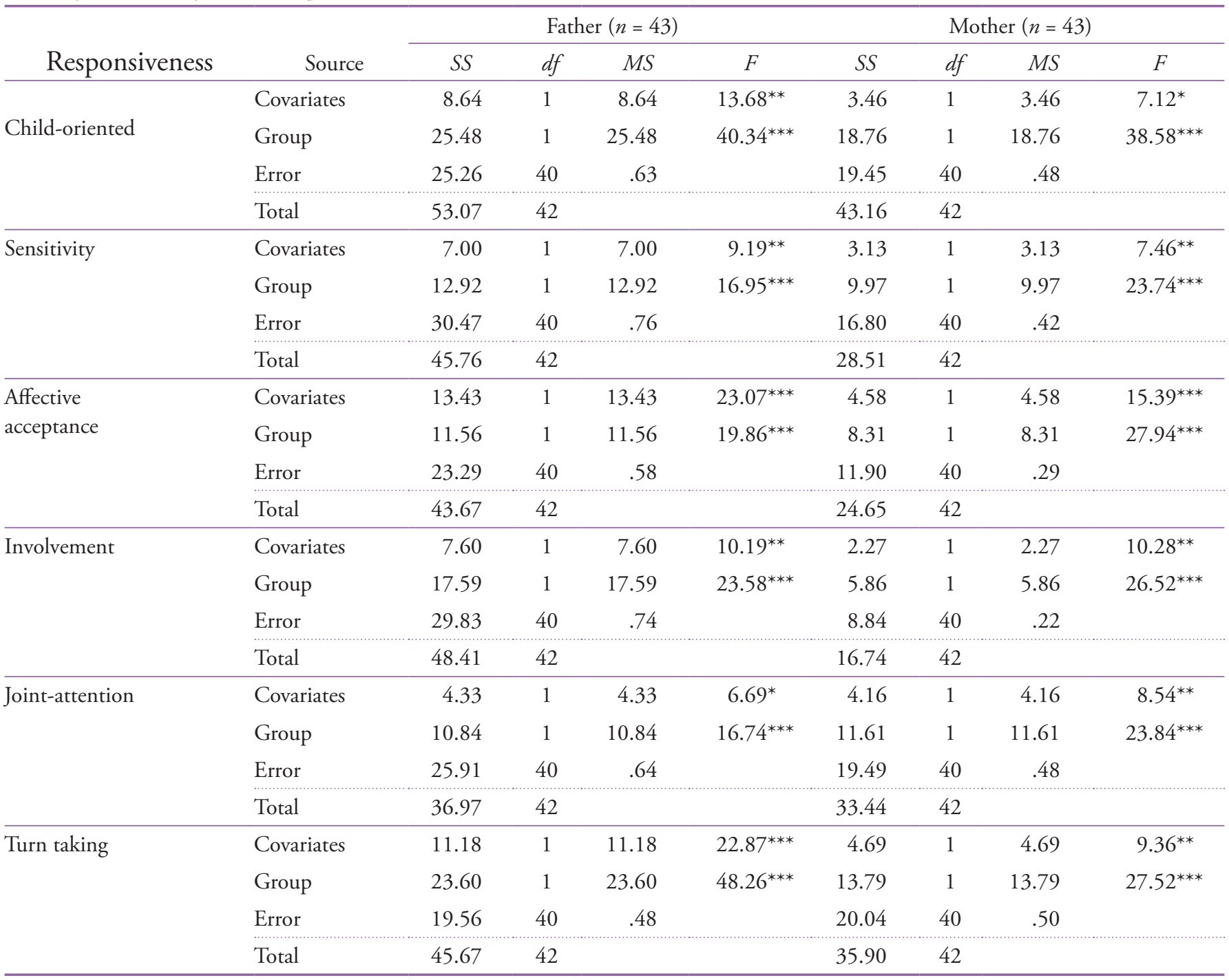

Note. $N=86$. Father $n=43$; Mother $n=43$.

${ }^{*} p<.05 .{ }^{* *} p<.01 .{ }^{* * *} p<.001$.

집중을 잘 하는 등 상호 반응성 수준이 높아졌다고 할 수 있다.

\section{부모공동양육의 질 변화}

본 부모교육 프로그램 실시 후, 사후검사에서 측정된 참여집 단 아버지의 공동양육 총점은 사전검사점수와 같았으며, 참여 집단 어머니의 공동양육 총점은 사전검사점수에 비해 .14점 증가하였다. 비교집단 아버지와 어머니의 사후검사점수는 사 전검사점수에 비해 .03점 증가하였다. 이러한 차이가 통계적 으로 유의한지를 분석한 결과, 참여집단 아버지와 어머니의 공동양육 점수에서 집단 간 유의미한 차이가 없었다.

\section{Discussion}

본 연구는 만 1 세 영아를 둔 맞벌이 부모를 대상으로 동반참여 블렌디드러닝 부모교육 프로그램을 개발하고 그 효과를 검증 하는 것을 목적으로 하였다. 프로그램 개발 및 효과 검증결과 에 대해 본 연구결과를 논의하면 다음과 같다.

\section{부모교육 프로그램 개발}

본 연구는 만 1 세 영아를 둔 맞벌이 가정 부모를 대상으로 언 어적 행동, 반응성 및 공동양육의 질 증진을 목표로 하여 부모 
동반참여 블렌디드러닝 부모교육 프로그램을 개발하였다. 프 로그램 개발은 교수체제개발의 기본 모형인 ADDIE 모형에 근거하되 변화이론을 접목하여 분석-설계-개발-실행-평가의 과정을 거쳐 이루어졌으며 각 단계별로 논의하면 다음과 같 다. 1단계에서는 문헌고찰 및 관련 이론들을 토대로 교육 대상 특성 및 프로그램 요구, 내용, 운영방식에 대해 분석하였고, 두 번째 설계 단계에서는 본 프로그램에 대한 구체적인 목표를 진술하고, 목표 달성을 위한 교육내용, 교수모형, 학습과정 및 교수학습방법과 프로그램의 효과 검증을 위한 평가방법을 설 계하였다. 이에 온, 오프라인을 통합한 격주제 블렌디드러닝 독립 교수모형을 적용한 총 8 주 12 회기의 부모교육 프로그램 을 구성하였다. 이는 매주 정해진 시간과 장소에 오프라인 수 업 참석이 어려운 맞벌이 부모들의 요구(Jung \& Kim, 2016; W. Park et al., 2018)와 온라인과 오프라인을 통합한 블렌디드러닝 이 융통성과 효율성, 학습의 확장성 측면에서 교육의 효과를 높인다는 선행연구(DeLacey \& Leonard, 2002; Eryilmaz, 2015; $\mathrm{Oh}, 2004)$ 을 반영한 것이다.

세 번째 개발 단계에서는 회기 및 집단형태, 강사를 선정 하고, 최종 선정된 교육내용을 운영방식에 맞게 회기별로 구 성, 조직하였다. 선행연구(E. Kim, Choi, Cho, Kim, 2009; J.-E. Kim, 2002; W. Park et al., 2018)에서 기존의 부모교육 대부분 이 대집단 형태의 전문가 강연, 일방적 강의 위주의 지식전달 방식, 일회성 활동 등으로 이루어짐으로써 행동의 변화나 생 활 적용으로의 가정 연계가 어렵다고 보고되고 있다. 이러한 단점을 보완하고자 본 프로그램은 15 인 이하의 소집단 형태 로 집단을 구성하고 직접 참여하는 체험, 실습이 주가 되는 워 크숍 형태의 학습자 중심 교육으로 이루어지도록 구성하였다. 따라서 오프라인 교육에서는 토의, 질의응답, 모의시연, 역할 극 등을 고루 실시함으로써 부모들이 회기마다 배운 지식을 토대로 양육기술을 연습해보도록 하였으며, 온라인 교육은 부 모들이 원하는 시간과 장소에서 개별적인 몰입학습이 이루어 지도록 하였다.

네 번째, 실행 단계에서는 개발된 부모교육 프로그램을 총 8 주 동안 만 1세 영아를 둔 부모 총 24쌍을 대상으로 서울과 경기지역 세 곳의 장소에서 매주 토요일 오전과 오후, 네 개 반 으로 실시하였다. 자녀 돌봄의 어려움을 해결하기 위해 반별 2-3명의 돌봄 교사를 배치하였으며, 교육시간과 장소를 다르 게 4 개 반을 운영하여 부모들의 선택권과 반이동성을 높임으 로써 교육생 이탈을 최소화하였다. 이는 향후 맞벌이 부모를 위한 교육 프로그램을 실행함에 있어서 부모들의 교육 참여 율 제고를 위한 방안으로 고려해볼 필요가 있다. 프로그램 진
행 중 참여집단 부모는 매 회기 온·오프라인 교육 후 과제를 수 행하였으며, 과제 수행에 대한 자기성찰을 해보고 온라인 교 육 공간에 글, 사진, 영상과 함께 일지를 작성, 제출하였다. 부 모들이 작성한 자아성찰일지가 총 250 개로 학습자 1 인 평균 5.2 개에 해당하는 개수인 점에 비춰볼 때, 맞벌이 부모들의 학 습동기와 참여율이 높고 스스로 변화하고자 하는 의지 또한 높다고 유추해볼 수 있다. 이는 맞벌이 부모가 일반 부모에 비 해 더 이른 시기부터 자녀양육정보와 교육의 필요성을 느끼 며, 부모교육 참여요구가 높다는 선행연구(E. Kim et al., 2009; W. Park et al., 2018)를 지지하는 결과이다. 이처럼 맞벌이 학습 자의 특성에 맞춘 운영방식과 교수학습방법을 체계화한 시도 는 교육 내용을 습득하고 내재화하는데 효과적이었으며, 이후 맞벌이 부모를 대상으로 하는 프로그램 운영 및 교수학습방법 개발에 시사하는 바가 된다.

마지막 평가 단계에서는 본 프로그램의 목표 달성 여부를 확인하기 위해 부모의 언어적 행동, 반응성, 공동양육 질에 대 한 효과를 검증하고, 프로그램 만족도 및 과제 수행에 대해 분 석하였다. W. Park 등(2018)은 부모들의 높아진 요구로 인해 과거보다 부모교육은 더 많이 시도되고 있으나 교육 내용과 운영 방법적인 측면에서 맞벌이 부모가 처한 상황과 요구 등 이 고려되지 않아 이들은 여전히 부모교육의 사각지대로 존재 한다는 문제점을 지적하였다(Y. Lee et al., 2016). 이에 비추어 볼 때, 본 부모교육 프로그램은 부모교육의 장벽이 높았던 맞 벌이 부모를 위해서 블렌디드러닝 기반의 전달방식으로 개발 과 실행이 이루어진 점에서 교육적 효과와 프로그램 적용성이 높다고 본다.

\section{부모교육 프로그램 효과 검증}

개발된 만 1 세 영아의 맞벌이 부모 동반참여 블렌디드러닝 부 모교육 프로그램의 효과를 검증한 결과를 구체적으로 살펴보 면 다음과 같다. 첫째, 영아지지 언어적 행동 중 영아를 순수하 게 지지하는 행동인 영아에게 내용을 설명하고, 영아의 의도 나 요구를 파악하기 위한 질문은 증가하였다. 자녀가 주의를 기울이는 것에 함께 주의를 공유하는 영아지지 언어적 행동은 영아로 하여금 참고하고 있는 놀잇감과 부모가 발화한 단어 를 연결짓는데 도움을 제공하여 언어 발달에 도움을 줄 수 있 다(Flynn \& Masur, 2007), 이렇듯 영아가 현재 주의 집중한 것 에 대해 언어화해주는 경우 어휘발달에 긍정적이라는 선행 연 구(Masur et al., 2013)의 결과를 참고하였을 때 참여집단 부모 의 이러한 변화는 바람직하다고 할 수 있다. 하지만 영아지지 
언어적 행동이지만 영아를 가르치기 위한 교수질문은 감소하 였다. 교수질문은 영아의도를 묻는 파악질문과 구별되는 것으 로, 영아지지 언어적 행동임에도 부모의 학습의도가 담겨있 는 질문이라는 점을 고려해 볼 때, 부모주도의 성격도 어느 정 도는 내포하고 있다고 볼 수 있다(Pine, 1992). 따라서 참여집 단 어머니의 교수질문이 감소했다는 것은 본 부모교육 프로그 램을 통해 만 1 세 영아 자녀를 대상으로 놀이를 가장한 학습 이 아닌 진짜 놀이를 하며 상호작용을 했다는 것을 의미하며, 교육 내용에서 다룬 놀이의 특징(진짜 놀이 vs 가짜 놀이)을 잘 이해한 것으로도 해석할 수 있다. 이는 취업모-영아 상호작용 에서 어머니가 학습과 언어환기가 많이 나타날수록 영아의 상 징놀이가 덜 이루어졌다고 보고한 S. Park과 Kim (2020)의 연 구에 비춰볼 때 매우 고무적인 결과라고 볼 수 있다. 부모가 영 아를 의도한 바대로 이끌기 위한 권유 또한 감소하였는데, 이 는 참여집단 부모들이 영아보다 앞서서 무엇인가를 제안하고 권유하기보다 반응해주는 영아지지 설명을 더 많이 사용함으 로써 상대적으로 영아지지 권유는 감소한 것이라 볼 수 있다. 마지막으로, 참여집단 부모 모두 영아가 주의를 집중하고 있 지 않은 사물과 관련하여 행동하도록 직접적으로 지시하는 행 동 지시, 주의를 전환시키는 주의 지시는 모두 감소하였다. 근 본적으로 놀이의 본연적 속성은 영아의 자발성과 주도성에 있 음을 고려할 때, 부모주도 언어적 행동이 줄었다는 것은 그 자 체로도 의미가 있다.

둘째, 참여집단 부모의 반응성 총점과 6 개의 하위 범주인 영아 중심성, 민감성, 정서적 수용성, 참여성, 공동주의, 상호 교환 모두에서 비교집단 부모보다 유의미하게 점수가 높았다. 이는 본 교육 프로그램을 통해 참여집단 부모가 만 1 세 영아 의 발달적 특징을 이해함으로써 평소 부정적으로 반응했던 영 아의 행동(예: 무한 반복하는 기능놀이)이나 잘 인식하지 못했 던 몸짓과 같은 비언어적 신호에 보다 민감하게 반응하게 된 것이라고 추론할 수 있다. 또한, 교육 주제를 전달하는 매개로 놀이를 사용함으로써 놀이의 특성에 대한 정보 습득과 놀이를 통한 반응적 상호작용 연습, 과제를 통한 지속적인 실천과 점 검을 통해 상호작용 기술 습득이 이루어졌으며 이후 상호작용 의 실제에서 태도의 변화로까지 이어진 결과로 간주된다. 특 히 참여집단 아버지들의 경우 사전점수에서 평균 2.96점으로 반응성 문항 척도가 5점 척도인 점을 감안할 때 보통 수준인 3 점보다도 낮은 수준이며, 3.6 3.7점에 분포한 다른 세 집단의 점수에 비해서도 상대적으로 낮았다. 하지만 사후 점수에서 교육에 참여하지 않은 비교집단 아버지들이 사전 점수에 비 해 점수가 다소 낮아진 반면, 교육에 참여한 참여집단 아버지
들은 4.24점으로 증가하였다. 부모역량 실태를 조사한 Jang \& Yoon (2014)는 아버지들의 부모역량이 어머니들에 비해 인식, 실행, 성장역량 즉 지식, 기술, 태도측면에서 대부분 낮게 나타 났다고 지적하며, 부모역량이 가변적이라는 점에서 부모 스 스로 부모역량을 높일 수 있도록 사회적으로 기회, 지원을 제 공하는 방안 마련의 필요성을 제언하였다. 본 연구에서 프로 그램 실시 이후 참여집단 아버지의 반응성의 차이가 어머니와 비슷한 수준으로 변화된 것은 이러한 교육기회와 경험을 통해 아버지의 부모역량이 높아질 수 있다는 가능성을 시사한다.

셋째, 부모의 공동양육 점수에서 집단 간 유의미한 차이가 나타나지 않았다. 본 프로그램에서 부모공동양육관계 증진을 목표로 아버지와 어머니의 동반참여 교육이 이루어진 점은 매 우 고무적이고, 공동양육에 관련한 지식전달과 함께 가정에서 협력적 공동양육을 실천해보는 생활적용이 지속되었음에도 불구하고 부모들의 태도변화 및 공동양육관계의 인식변화로 까지는 연결이 되지 못했다. 향후 부모공동양육의 질을 증진 시키기 위해 좀 더 긴 시간의 교육참여와 구체적인 양육 사례 중심의 교육내용의 보완 등 다양한 시도가 요구된다.

본 연구에 대한 제한점 및 후속 연구 제언은 다음과 같다. 첫째, 본 프로그램은 온·오프라인을 격주로 운영하는 블렌디 드러닝 전달방식으로 개발, 실행되었다. 만족도 조사에서 전 달 방식에 대한 평가가 비교적 높고 일관된 결과가 산출되었 으나 일부 대상자들의 경우 온라인 교육에 소홀한 경우가 보 고되었다. 추후 온라인 교육 참여율을 더 높이는 시스템 방안 을 고려할 필요가 있다. 둘째, 질문지를 통해 부모 공동양육의 변화를 측정하였다. 아버지, 어머니가 상대 배우자의 공동양 육에 대해 인식하는 정도를 체크하기 때문에 후속 연구에서는 아버지-어머니-영아 3자간 상호작용 맥락에서 나타나는 부모 의 협력, 갈등, 삼각화 관계를 관찰하고 이를 검증하는 방식도 시도될 필요가 있다. 마지막으로, 본 연구는 부모의 변화만을 검증하였는데, 부모의 변화가 영아의 실제 발달에 어떠한 영 향을 미치는지, 교육의 효과가 계속 유지되는지 등 부모-자녀 간 영향력을 지속적으로 살펴볼 필요가 있다.

이러한 제한점에도 불구하고 본 연구가 갖는 의의는 다음 과 같다. 그동안 부모교육에서 소홀하게 다뤄졌던 만 1 세 영아 를 둔 맞벌이 아버지, 어머니 모두를 대상으로 이들의 긍정적 인 부모역할전이가 이루어질 수 있는 초석을 마련했다는 점, 부모공동양육관계에 초점을 맞추어 블렌디드러닝 기반 교육 프로그램을 개발, 실행 및 그 효과를 검증하였다는 점에서 의 의를 찾을 수 있다. 


\section{Notes}

This article is a part of the first author's doctoral dissertation submitted in 2020, and was presented at the 2020 Annual Fall Online Conference of the Korean Association of Child Studies.

\section{Conflict of Interest}

No potential conflict of interest relevant to this article was reported.

\section{Ethics Statement}

All procedures of this research were reviewed by IRB (7001988202007-HR-654-03).

\section{References}

\section{In English}

Acree, L., Gibson, T., Mangum, N., Wolf, M. A., Kellogg, S., \& Branon, S. (2017). Supporting school leaders in blended learning with blended learning. Journal of Online Learning Research, 3(2), 105-143.

Bornstein, M. H. (2002). Parenting infants. In M. H. Bornstein (2nd ed.), Handbook of parenting (Vol. 1, pp. 3-43). Mahwah, NJ: Lawrence Erlbaum Associates.

DeLacey, B. J., \& Leonard, D. A. (2002). Case study on technology and distance in education at the Harvard Business School. Journal of Educational Technology \& Society, 5(2), 13-28.

Eryilmaz, M. (2015). The effectiveness of blended learning environments. Contemporary Issues in Education Research, 8(4), 251-256. doi:10.19030/cier.v8i4.9433

Flynn, V., \& Masur, E. F. (2007). Characteristics of maternal verbal style: Responsiveness and directiveness in two natural contexts. Journal of Child Language, 34(3), 519-543. doi:10.1017/S030500090700801X

Frodi, A., Bridges, L., \& Grolnick, W. (1985). Correlates of mastery-related behavior: A short-term longitudinal study of infants in their second year. Child Development, 56(5), 1291-1298. doi:10.2307/1130244

Garbarino, J., Vorrasi, J. A., \& Kostelny, K. (2002). Parenting and public policy. In M. H. Bornstein (Ed.), Handbook of parenting (2nd ed., Vol. 5, pp. 487-507). Mahwah, NJ:
Lawrence Erlbaum Associates.

Gates, M. K. (2007). Differences in parenting styles and responsiveness: A comparison of mothers and fathers of toddlers (Masters's thesis). Available from ProQuest Dissertations \& Theses Global database. (UMI No. MR33169)

Kolb, D. A. (1984). Experiential learning: Experience as the source of learning and development. Englewood Cliffs, NJ: Prentice Hall.

LeBarton, E. S., Goldin-Meadow, S., \& Raudenbush, S. (2015). Experimentally induced increases in early gesture lead to increases in spoken vocabulary. Journal of Cognition and Development, 16(2), 199-220. doi:10.1080/15248372.201 3.858041

LeRoy, M., Mahoney, A., Pargament, K. I., \& DeMaris, A. (2013). Longitudinal links between early coparenting and infant behaviour problems. Early Child Development and Care, 183(3-4), 360-377. doi:10.1080/03004430.2012.711588

Mantyla, K. (2001). Blending e-learning. Alexandria, VA: ASTD.

Margolin, G., Gordis, E. B., \& John, R. S. (2001). Coparenting: A link between marital conflict and parenting in twoparent families. Journal of Family Psychology, 15(1), 3-21. doi:10.1037/0893-3200.15.1.3

Masur, E. F., Flynn, V., \& Lloyd, C. A. (2013). Infants' behaviors as antecedents and consequents of mothers' responsive and directive utterances. First Language, 33(4), 354-371. doi:10.1177/0142723713490603

Myers-Walls, J. A., \& Dworkin, J. (2015). Parenting education without borders: Web-based outreach. In J. J. Ponzetti (Ed.), Evidence-based parenting education (pp. 123-140). New York: Routledge.

Pancsofar, N., \& Vernon-Feagans, L. (2006). Mother and father language input to young children: Contributions to later language development. Journal of Applied Developmental Psychology, 27(6), 571-587. doi:10.1016/j.appdev.2006.08.003

Pine, J. M. (1992). Maternal style at the early one-word stage: Reevaluating the stereotype of the directive mother. First Language, 12(35), 169-186. doi:10.1177/014272379201203504

Rivera, J. H. (2017). The blended learning environment: A viable alternative for special needs students. Journal of Education and Training Studies, 5(2), 79-84. doi:10.11114/jets. v5i 2.2125

Schoppe-Sullivan, S. J., Mangelsdorf, S. C., Frosch, C. A., \& McHale, J. L. (2004). Associations between coparenting and marital behavior from infancy to the preschool years. Journal of Family Psychology, 18(1), 194-207. doi:10.1037/0893-3200.18.1.194

Shuler, J. (2012). Joint picture book reading in monolingual and bilingual parent-child dyads: The role of parent-child interactional quality (Unpublished doctoral dissertation). Georgetown University, Washington, D. C. 
Singh, H. \& Reed, C. (2001) Achieving success with blended learning. Centra Software. ASTD State of the Industry Report. American Society for Training and Development.

Smith, C., Perou, R., \& Lesesne, C. (2002). Parent education. In M. H. Bornstein (Ed.), Handbook of parenting (2nd ed., Vol. 4, pp. 389-409). Mahwah, NJ: Lawrence Erlbaum Associates.

Stern, D. N. (2002). The first relationship: Infant and mother. Cambridge, MA: Harvard University Press.

Thorne, K. (2003). Blended learning: How to integrate online \& traditional learning. London: Kogan Page.

van Egeren, L. A., \& Hawkins, D. P. (2004). Coming to terms with coparenting: Implications of definition and measurement. Journal of Adult Development, 11(3), 165-178.

\section{In Korean}

Bae, J.-H., Cho, M.-Y., Bong, J.-Y., \& Kim, E.-H. (2011). Parents' experiences and expectations of parent education and involvement in early schooling. Korean Journal of Early Childhood Education, 31(3), 279-304.

Cha, D.-W., Moon, Y.-E., Yoon, J-H., \& Kim, Y.-R. (2005). A pilot study of the learning involvement and achievement in blended learning. Korean Business Education Review, 38(1), 3-18.

Choi, H., \& Kim, M. S. (2019). The relationship between infants' response on communication with mothers and their vocabulary. Journal of Parent Education, 11(1), 135-156.

Chung, M.-R., Yee, B.-S., \& Moon, W.-S. (2012). The research trends on infants program. The Journal of Korea Open Association for Early Childhood Education, 17(2), 127-149.

Jang, H. J., \& Yoon, E. J. (2014). The current status of parental capacity for children's happiness. Journal of Korean Child Care and Education, 10(2), 295-317.

Jung, B.-M,. \& Kim, N.-H. (2016). Parent educational experiences and needs of double-income parents who have the first child in infancy. The Korean Journal Child Education, 25(3), 377-393. doi:10.17643/KJCE.2016.25.3.20

Kim, E., Chang, H., Kim, M., \& Walker, S. (2011). Yeong-yuagi janyeo bumo teugseongbyeol bumogyoyug ganghwa bang-an [영유아기 자녀 부모 특성별 부모교육 강화 방안](Report No. 2011-16). Retrieved from Korea Institute of Child Care and Education website: http://www.kicce.re.kr/

Kim, E., Choi, J., Cho, H., \& Kim, K. (2009). Yug-ajiwongigwan bumogyoyug.cham-yeo hwalseonghwa bang-an yeongu [육아 지원기관 부모교육.참여 활성화 방안 연구](Report No. 2009-08). Retrieved from Korea Institute of Child Care and Education website: http://www.kicce.re.kr/

Kim, G. (2017). Current development status of the parent education program and an analysis of the program. Journal of Parent Education, 9(4), 273-292.
Kim, H. J,. \& Kim, M. S. (2019). The differences in toddler's symbolic play level and play involvement according to toddler-mother joint attention. Journal of Parent Education, 11(4), 169-186. doi:10.36431/JPE.11.4.9

Kim, J.-E. (2002). Need assessment of young children mothers for contents of parent education. The Korea Association of Child Care and Education, 28, 225-243.

Kim, M. S. (2016). The necessity and direction of parent education. Proceedings of Korean Women's Development Institute A Study for Revitalizing Parent Education for Family Happiness (pp. 2-26). Seoul, Korea: Korean Women's Development Institute.

Kim, M. S. (2019, March 30). Childbirth and parenting: The changing quality of parent-child relationships [Video]. Open Lectures. https://openlectures.naver.com/contents?contents $\mathrm{Id}=143457 \&$ rid $=2945$

Kim, M. S., Cho, H. R., Park, Y. L., \& Shin, H. Y. (2013). The study of parents and children regarding play: Focused on parental play beliefs and play participation. Journal of Parent Education, 5(1), 37-53.

Kim, M. S., \& Sung. J. H. (2002). The relationship between infant's language and play. Korean Journal of Child Studies, 23(5), 19-34.

Ko, J. M., \& Lee, S. Y. (2010). A comparison of mothers' and fathers' responsiveness while playing with their two-yearold children. Korean Journal of Early Childhood Education, 30(2), 147-165.

Lee, Y., Kim, A., \& Lim, J. (2016). Abeoji yang-yugcham-yeo siltae mich yeoglyang ganghwa bang-an [아버지 양육참여 실 태 및 역량 강화 방안](Report No. 2016-16). Retrieved from Korea Institute of Child Care and Education website: http://www.kicce.re.kr/

Lee, Y. S., \& Kim, M. S. (2013). The relationships among infants' nonverbal communication, maternal verbal behaviors and the infants' acquisition of vocabulary. Korean Journal of Child Studies, 34(2), 1-25. doi:10.5723/KJCS.2013.34.2.1

Oh, I. (2004). Blended learning trends analysis: Korean trends \& comparative study with foreign data. Journal of Corporate Education and Talent Research, 6(1), 41-62.

Park, S., \& Kim, M.-S. (2020). The differences in interaction contents and verbal behavior and toddler's play level. The Journal of Korea Open Association for Early Childhood Education, 25(1), 263-285. doi:10.20437/KOAECE25-1-11

Park, S.-H., \& Choi, S.-W. (2010). Needs assessment for developing the blended learning-based parent education program (Parenting cross-fertilizing program). The Journal of Lifelong Education and HRD, 6(2), 21-39.

Park, W., Lee, J., \& Ye, H. (2018). Yeong-yua bumogyoyng sagagjidae haesoleul wihan sibeomsa-eob-majbeol-i mich abeoji daesang bumogyoyug [영유아 부모교육 사각지대 해소를 위한 시 
범사업-맞벌이 및 아버지 대상 부모교육](Report No. 2018-29). Retrieved from Korea Institute of Child Care and Education website: http://www.kicce.re.kr/

\section{ORCID}

Hye Young Shin http://orcid.org/0000-0002-5828-6190

Myoung Soon Kim

Received January 13, 2021

Revision received February 24, 2021

Accepted March 22, 2021 